\title{
ANALISIS SEJARAH PERPAJAKAN MAJAPAHIT DALAM MENINGKATKAN EKONOMI DI ERA OTONOMI
}

\author{
Sarip \\ Fakultas Hukum \\ Universitas Muhammadiyyah Cirebon \\ e-mail: sarip_anisa@yahoo.co.id
}

\begin{abstract}
In Indonesia before the arrival of Europeans, kingdoms such as Majapahit and Mataram were familiar with land and indirect taxes on merchandise. Royal officials of tax collectors are not paid by the kingdom, so often they excessive taxes. Individual tribute or group of people given to the king or ruler as a form of respect and submission to the rule of the king or ruler of an Indonesian territory is a form of tax in the era of kingdoms in Indonesia grow. The tribute is in the form of crops and trade in trade goods. In return, the people receive security services and order security. In the kingdom of Mataram kings have carried out a selfsufficient and autonomous life. The surrender is greater to the economic interests of the region or kingdom, to finance the administration of the local government, and to finance the land and the power of the kingdom.
\end{abstract}

Keywords: Taxes, Powers, Income, Autonomy.

\begin{abstract}
Abstrak
Di Indonesia sebelum kedatangan bangsa Eropa, kerajaan seperti Majapahit dan Mataram sudah mengenal bentuk pajak tanah dan pajak tidak langsung terhadap barang dagangan. Pejabat kerajaan pemungut pajak tidak digaji oleh kerajaan, maka sering kali mereka menerapkan pajak secara berlebihan. Upeti perorangan ataupun kelompok orang diberikan kepada raja atau penguasa sebagai bentuk penghormatan dan tunduk patuh pada kekuasaan raja atau penguasa suatu wilayah Indonesia merupakan bentuk pajak pada zaman kerajaankerajaan di Indonesia tumbuh. Upeti tersebut berupa hasil bumi dan pemajakan barang perdagangan. Sebagai imbalannya maka rakyat mendapat pelayanan keamanan dan jaminan ketertiban. Di kerajaan Mataram raja-raja sudah melaksanakan hidup swasembada dan otonom. Penyerahan tersebut lebih besar pada kepentingan ekonomi daerah atau kerajaan, membiayai penyelenggaraan pemerintahan setempat, dan membiayai pertanahan dan kekuatan kerajaan.
\end{abstract}

Kata Kunci: Pajak, Kekuasaan, Pendapatan, Otonomi. 


\section{PENDAHULUAN}

Pendapatan Asli Daerah (PAD) diperlukan untuk pembangunan daerah, salah satu bersumber PAD yakni pajak daerah. ${ }^{1}$ Pajak daerah merupakan gejala sosial yang terdapat di daerah, tanpa ada masyarakat di daerah, tidak ada pajak daerah. Masyarakat yang dimaksud adalah masyarakat hukum atau gemeinschaft menurut Ferdinand Tonnies. Manusia hidup bermasyarakat masing-masing membawa hak dan kewajiban.

Proses timbal balik antara pemerintah daerah dan masyarakat daerah, melahirkan hak dan kewajiban. Adanya hubungan timbal balik sebagai sebagai bentuk pembatasan HAM guna menghindari pergesekan yang akan berakibat buruk terhadap ekonomi lokal di era otonomi. ${ }^{2}$ Pemerintah darah selaku pihak yang menjalankan penyelenggaraaan otonomi memerlukan modal untuk membiayai pembangunan, kewajiban untuk mengebangkan ekonomi lokal.

Sejarah Majapahit merupakan cermin kemajuan negara kerajaan dan ketertiban masyarakat. Kemajuan pembangunan Majapahit tidak terlepas dari pajak yang memberikan solusi terhadap perekonomian masyarakat, melalui membuat aturan tentang pajak. Sebagaimana dikatakan Satjipto Rahardjo,

“...kebenaran hukum tidak dapat
ditafsirkan semata-mata sebagai
kebenaran undang-undang tetapi
harus dipahami sebagai kebenaran
prinsip keadilan yang mendasari
undang-undang...".3

Analisis sejarah perpajakan kerajaan Majapahit dalam rangka pencapaian kesejahteraan masyarakat daerah. Kemudian

\footnotetext{
${ }^{1}$ Sjachran Basah, Rangkuman Sari Perkuliahan Ilmu Negara I (Bandung: Grafika Unit II, 1967), 30.

${ }^{2}$ Siti Kurnia Rahayu, Perpajakan (Konsep, Teori, dan Isu) (Jakarta: Kencana, 2006), 6.

${ }^{3}$ Satjipto Rahardjo, Penegakan Hukum Suatu Tinjauan Sosiologis (Yogyakarta: Genta Publishing, 2009), 1.
}

dalam rangka menerapkan nilai-nilai kemasyalahatan di era otonomi yang dilakukan dengan cara menggali sumber sejarah, untuk diaplikasikan pada saat sekarang. Hal ini diperlukan suatu pemahaman yang baik baik dari segi nilai kearifan lokal sendiri maupun dilihat dari sendi-sendi kemasyalahatan manusia di daerah dalam menyongsong otonomi daerah. Dalam berbagai penulisan belum ditemukan tentang analisis pajak kerajaan Majapahit dilihat dari sisi ekonomi untuk kesejahteraan daerah. Maka, hal ini menjadi awal untuk melihat dan melakukan kajian tersendiri bagi penulis. Seperti Satjipto Supradikno penulisannya berfokus pada peradaban Jawa dan tidak menggali peradaban tersebut pada ekonomi ataupun otonomi daerah. ${ }^{4}$ Mardismo dalam tulisannya hanya membicarakan tentang keuangan daerah tanpa melihat masa lalu tentang kerajaan. ${ }^{5}$ Selanjutnya dalam tulisan Krisna Bayu Adji dan Sri Wintala Achmad memfokuskan pada sejarah perang di bumi Jawa dan pembagian kekuasaan pada daerah dengan tidak melihat nilai kesejahteraan ekonomi pada masyarakat di daerah sebagai perwujudan otonomi. ${ }^{6}$

\section{LITERATURE REVIEW}

Negara harus aktif menyelenggarakan kemakmuran warganya, untuk kepentingan seluruh Rakyat. ${ }^{7}$ Otto von Bismark mengemukakan prinsip teori welfare state, yakni: bahwa negara atau pemerintah bertanggung jawab penuh untuk menyediakan semua kebutuhan rakyatnya dan tidak dapat dilimpahkan kepada

\footnotetext{
${ }^{4}$ Rahardjo Supratikno, Peradaban Jawa (Jakarta: Komunitas Bambu, 2002), 13.

${ }^{5}$ Mardiasmo, Otonomi dan Managemen Keuangan Daerah (Yogyakarta: Penerbitan Andi, 2002), 24.

${ }^{6}$ Krisna Bayu Adji dan Sri Wintala Achmad, Sejarah Perang-perang di Bumi Jawa dari Mataram Kuno hingga Pasca Kemerdekaan Republik Indonesia, (Yogyakarta: Araska, 2014), 17.

${ }^{7} \mathrm{Abu}$ Daud Busroh, Ilmu Negara (Jakarta: Bumi Aksara, 1990), 55.
} 
siapapun. ${ }^{8}$ Otto von Bismark mewacanakan konsep kesejahteraan masyarakat (social welfare) tersebut secara konkrit ke dalam bentuk model program kesejahteraan masyarakat bagi pemerintahan modern (The model of modern government social security program). Tujuan pelimpahan wewenang adalah karena tugas penyelenggaran negara tidak sekedar menjaga ketertiban, tetapi lebih dari itu, ketertiban harus diupayakan agar memenuhi rasa keadilan. ${ }^{9}$

Konsep welfare state sendiri merupakan perkembangan lanjutan dari konsep rule of law pada negara hukum klasik. Rule of law menurut paham A.V. Dicey mengandung tiga unsur, yakni equality before the law (setiap manusia mempunyai kedudukan yang sama derajatnya dihadapan hukum), constitution bases on human right (konstitusi harus mencerminkan hak asasi manusia), dan supremation of law (kekuasaan tertinggi terletak pada hukum/kedaulatan hukum). ${ }^{10}$

Atas dasar kesadaran hukum, pada masa yang kemudian, tugas pemerintahan berkembang ke arah fungsi perlindungan, tentunya hal sedemikian juga terjadi pada daerah-daerah di Indonesia. Merujuk Pasal 23A UUD 1945 "Pajak dan pungutan lain yang bersifat memaksa untuk keperluan negara diatur dengan undang-undang". ${ }^{11}$ Ketentuan tersebut menjadi landasan konstitusional bagi pemungutan pajak daerah dan retribusi daerah di Indonesia. Selain juga menyiratka suatu falsafah bahwa pajak dan retribusi daerah yang dipungut harus berdasarkan undang-undang.

Dari beberapa topik penelitian yang telah dipaparkan di atas, ternyata belum ada tinjauan secara khusus dan komprehensif

${ }^{8}$ Otto von Bicmark dalam Tjip Ismail (eds.), Pengaturan Pajak Daerah Indonesia (Jakarta: Yellow Printing, 2007), 36.

${ }^{9}$ Azhary, Negara Hukum Indonesia, Analisis Yuridis Normatif tentang Unsur-unsurnya (Jakarta: Universitas Indonesia, 1995), 43.

${ }^{10}$ A.V. Dicey dalam Tjip Ismail (eds.), Pengaturan Pajak Daerah Indonesia 37.

${ }^{11}$ UUD 1945 hasil amandemen ketiga. tentang analisis perpajakan Majapahit dalam meningkatkan ekonomi di era otonomi. Dengan menggunakan pendekatan sejarah, selain nantinya akan tergambar karakteristik praktik perpajakan di era Majapahit yang pada akhirnya diharapkan penelitian ini juga akan mengungkapkan nuansa pembaharuan pemikiran perpajakan meningkatkan ekonomi di era otonomi. Di sinilah letak perbedaan studi ini dengan studi-studi yang telah dilakukan sebelumnya.

\section{METODOLOGI PENELITIAN}

Penelitian ini termasuk dalam kategori penelitian normatif, melalui berbagai upaya untuk mengkaji dan menganalisis secara mendalam berbagai ketentuan hukum yang berkaitan dengan masalah penelitian (study of law in the book). Jenis data yang digunakan meliputi data sekunder. Analisis data dengan metode analisis deskriptif kualitatif, yakni menguraikan data dalam bentuk kalimat yang tersusun secara sistematis, lengkap dan berdasarkan pokok bahasan sehingga mempermudah dalam pengambilan kesimpulan. Penarikan kesimpulan menggunakan metode deduktif, yaitu dengan cara berfikir di dalam pengambilan kesimpulan terhadap permasalahan yang diajukan secara umum, kemudian ditarik pada hal-hal yang bersifat khusus.

\section{KONSEP DASAR}

Pengembangan pembangunanan daerah dalam perangkat peraturan perundangundangan tidak akan dapat dimanfaatkan oleh daerah apabila paradigma pajak daerah dan retribusi daerah tidak berubah. Pandangan desentralisasi di Indonesia, merupakan pelimpahan wewenang dari pemerintah pusat kepada pemerintahan daerah, dalam kerangka Negara Kesatuan Republik Indonesia (NKRI). Pelimpahan kewenangan dari pemerintahan pusat ke pemerintahan daerah diharapkan menjadi efektif dalam mencapai pokok pembangunan daerah, meningkatkan askes pelayanan dan pekerjaan, meningkatkan 
peran serta warga dalam mengambil keputusan yang mempengaruhi kehidupan warga. ${ }^{12}$ Paradigma pembangunan daerah di Indonesia secara tranparan dapat dilihat dari adanya undang-undang pemerintahan daerah pasca reformasi. ${ }^{13}$ Sejalan dengan pendapat K.J. Davey yang menyatakan:

Pajak pendapatan merupakan sumber penerimaan yang paling potensial dan jelas hubungannya dengan kemampuan pembayar oleh wajib pajak, struktur tarifnya dengan mudah menjadi progresif. ${ }^{14}$

Persyaratan yang paling jelas bagi pendapatan daerah adalah sumber pendapatan daerah harus menghasilkan pendapatan yang besar dalam kaitannya dengan seluruh atau sebagian biaya pelayanan yang akan dikeluarkan, untuk membiayai pembangunan daerah. ${ }^{15}$ Seluruh atau sebagian biaya pelayanan yang akan dikeluarkan. Sering kali di dalam undangundang pemerintahan daerah mempunyai banyak jenis pajak dan retribusi, tetapi tidak ada yang menghasilkan lebih besar dari persentase anggaran pengeluarannya. Tentu, dapat menimbulkan banyak kerugian bagi

\footnotetext{
${ }^{12}$ Karena tujuan negara adalah kesempurnaan warga berdasarkan atas keadilan. Lihat Abu Daud Busroh dan Abubakar Busro, Asasasas Hukum Tata Negara (Jakarta: Ghalia Indonesia, 1983), 109. Lihat juga Donald A. Rumokoy, Dimensi-dimensi Pemikiran Hukum Administrasi Negara, Cet-2 (Yogyakarta: UII Press, 2002), 1.

${ }^{13}$ Undang-Undang Nomor 22 Tahun 1999 tentang Pemerintahan Daerah dan kemudian digantikan dengan Undang-Undang Nomor 32 Tahun 2004 tentang Pemerintahan Daerah.

${ }^{14}$ Kenneth J. Davey, Pembiayaan Pemerintah Daerah Praktik Internasional dan Relevansinya bagi Dunia Ketiga, terj. Amanullah, et al. (Jakarta: Universitas Indonesia, 1988), 109.

${ }^{15}$ Prinsip yang demikian merupakan prinsip dalam ilmu ekonomi, ilmu ekonomi sendiri mempunyi prinsi "dengan pengorbanan yang minimal menghasilkan yang maksimal, begitu juga dalam pemungutan pajak daerah dan retribusi daerah jangan sampai terjadi pengeluran untuk pemungutan pajak daerah dan retribusi daerah lebih besar dibandingkan dengan pendapatan dari sector pajak daerah dan retribusi daerah.
}

daerah, dengan melihat ongkos pungut akan menjadi besar.

Pada akhirnya, upaya administrasi terbagi-bagi pembebanan sulit dicapai secara adil, kesabaran warga akan hilang dengan banyaknya pungutan yang kecilkecil dan kesan yang tidak benar dapat timbul terhadap kemampuan keuangan pemerintahan daerah. Biasanya dikehendaki agar memusatkan perhatian pada usaha pemungutan pajak daerah dan retribusi daerah yang menghasilkan pendapatan besar, untuk dapat membiayai sebagian besar pengeluaran atas pelayanan yang diberikan oleh pemerintah daerah terhadap warga. ${ }^{16}$

Peningkatan pendapatan daerah dapat dihubungkan dengan pertumbuhan ekonomi nasional menyebabkan permintaan pelayanan yang berkualitas tinggi. Sebenarnya tidak ada batas harapan-harapan dapat dipenuhi secara absolut; begitu pendidikan dasar tersedia untuk semua orang maka timbul permintaan yang lebih banyak untuk pendidikan dasar dan menengah timbul permintaan sekolah taman kanak-kanak. Banyaknya usaha perbaikan dalam perluasan pelayanan tersebut dijadwalkan dalam perencanaan pembangunan nasional. ${ }^{17}$

Kalau biaya meningkat maka pendapatan juga harus meningkat. Paling tidak, dari sudut pemerintah daerah dikehendaki agar pajak daerah dan retribusi daerah dapat menunjukan elastisitasnya, ${ }^{18}$ yakni kemampuan untuk menghasilkan tambahan pendapatan agar dapat menutup

${ }^{16}$ Adrian Sutedi, Iimplikasi Hukum Atas Sumber Pembiayaan Daerah dalam Kerangka Otonomi Daerah (Jakarta: Sinar Grafika, 2009), 94.

${ }^{17}$ Adrian Sutedi, Iimplikasi Hukum Atas Sumber Pembiayaan Daerah dalam Kerangka Otonomi Daerah, 94-95.

${ }^{18}$ Elastis yang dimaksudkan adalah lentur yakni mudah menyesuaikan diri dengan keadaan masyarakat daerah. Selain itu pengertian elastis sendiri adalah mudah berubah bentuknya dan mudah kembali ke bentuk asal. Departemen Pendidikan Nasional, Kamus Besar Bahasa Indonesia Edisi III (Jakarta: Balai Pustaka, 2005), 239. 
tuntutan yang sama atas kenaikan pengeluaran pemerintah daerah dan dasar pengenaan pajak daerah dan retribusi daerah berkembang secara otomatis misalnya apabila harga-harga meningkat, penduduk disuatu daerah berkembang, dan pendapatan individu bertambah. Dalam hubungan elastisitas mempunyai dua dimensi, yaitu:

1. Pertumbuhan potensi dari dasar pengenaan pajak daerah dan retribusi daerah itu sendiri;

2. Kemudahan untuk memungut pertumbuhan pajak daerah dan retribusi daerah.

Perbedaan tanggapan dari Advalorem pajak penjualan dan pajak atas harta tetap terhadap tingkat inflasi memberikan gambaran hal tersebut. Pada saat hargaharga meningkat, dasar pengenaan untuk pajak penjualan-nilai kotor penjualan yang dikenakan pajak juga akan bertambah. Kalau pajak tersebut merupakan persentase dari harga barang dan jasa, maka hasilnya akan meningkat secara otomatis sesuai dengan perkembangan dasar pengenaan pajaknya. Inflasi biasanya mendorong tingkat harga atau nilai sewa harta tetap. Pertumbuhan potensi dasar pengenaan pajak atas harta tetap hanya dapat digali kalau tarifnya ditingkatkan atau hartanya dinilai kembali secara administrasi pajak. Dalam hal lain, elastisitas tergantung pada kepekaan keputusan yang diambil atau tuntutan atas kemampuan administrasinya. ${ }^{19}$ Begitu juga dengan retribusi, apabila tingkat kemakmuran masyarakat bertambah maka pemerintah daerah dapat mengenakan retribusi dalam bentuk jasa dan layanan yang bersifat umum.

Kriteria utama keadilan beban pengeluaran pemerintah daerah haruslah dipikul oleh semua golongan dalam warga sesuai dengan kekayaan, kesanggupan masing-masing golongan, dan penggunaan

\footnotetext{
${ }^{19}$ Adrian Sutedi, Iimplikasi Hukum Atas Sumber Pembiayaan Daerah dalam Kerangka Otonomi Daerah, 96.
}

jasa yang diberikan oleh pemerintah daerah. Konsep ini merupakan konsep keadilan sosial yang secara luas dianut oleh hampir semua pemerintahan. Namun dalam praktik tidak selaludilaksanakan. Sebagai suatu konsep, hal ini berarti perpajakan merupakan suatu alat distribusi kembali, golongan kaya menyumbang lebih besar daripada nilai pelayanan yang diberikan kepada mereika dan golongan miskin lebih kecil. Dalam praktik, hal ini juga dapat dicapai kalau golongan kaya menikmati manfaat yang lebih sedikit dari pengelauran pemerintah. $^{20}$ Keadilan dalam perpajakan daerah dan retribusi daerah mempunyai tiga dimensi, yakni antara lain sebagai berikut:

1. Dimensi pemerataan secara vertikalhubungan dalam pembebanan pajak atas tingkat pendapatan yang berbeda-beda; ${ }^{21}$

2. Dimensi keadilan horizontal-hubungan pembebanan pajak dan retribusi dengan sumber pendapatan; ${ }^{22}$
3. Dimensi Ketiga, adalah keadilan georafis. $^{23}$

\footnotetext{
${ }^{20}$ Adrian Sutedi, Iimplikasi Hukum Atas Sumber Pembiayaan Daerah dalam Kerangka Otonomi Daerah, 96.

${ }^{21}$ Secara umum, pajak itu baik kalau pajak tersebut 'pogresif: yakni persentase pendapatan seseorang yang dibayarkan untuk pajak bertambah sesuai dengan tingkatan pendapatannya. Pemebebanan masih dapat diterima kalau dikenakan secara proposional yakni kalau persentase pendapatan yang dibayarkan untuk pajak sama untuk semua tingkat pendapatan. Pajak baik apabila pembeliannya 'regresif' yakni persentase pendapatan yang dibayarkan untuk pajak menurun dengana danya kenaikan tingkat pendapatan. Adrian Sutedi, Iimplikasi Hukum Atas Sumber Pembiayaan Daerah dalam Kerangka Otonomi Daerah, 97.
}

${ }^{22}$ Seseorang yang menerima gaji seharusnya tidak membayar pajak lebih besar daripada seseorang dengan pendapatan yang sama dari bisnis atau pertanian; seorang petani yang mengusahakan tanaman ekspor seharusnya tidak membayar lebih besar daripada petani dengan pendapatan sama di bidang tanaman pangan. Di bidang retribusi juga dapat dilihat dari kualitas pelayanan yang diberikan oleh pemerintah.

${ }^{23}$ Pembebanan pajak harus adil antara penduduk diberbagai daerah. Orang seharusnya tidak dibebani pajak lebih berat hanya karena mereka 
PEMBAHASAN DAN DISKUSI

Pajak sebagai Bentuk Rasa Penundukan Diri pada Sang Penguasa dalam Bentuk Pengkastaan

Di Indonesia sebelum kedatangan bangsa Eropa, kerajaan seperti Majapahit dan Mataram sudah mengenal bentuk pajak tanah dan pajak tidak langsung terhadap barang dagangan. Pejabat kerajaan pemungut pajak tidak digaji oleh kerajaan, maka sering kali mereka menerapkan pajak secara berlebihan. Upeti perorangan ataupun kelompok orang diberikan kepada raja atau penguasa sebagai bentuk penghormatan dan tunduk patuh pada kekuasaan raja atau penguasa suatu wilayah Indonesia merupakan bentuk pajak pada zaman kerajaan-kerajaan di Indonesia tumbuh.

Upeti tersebut berupa hasil bumi dan pemajakan barang perdagangan. Sebagai imbalannya maka rakyat mendapat pelayanan keamanan dan jaminan ketertiban. Di kerajaan Mataram raja-raja sudah melaksanakan hidup swasembada dan otonom. Penyerahan tersebut lebih besar pada kepentingan ekonomi daerah atau kerajaan, membiayai penyelenggaraan pemerintahan setempat, dan membiayai pertanahan dan kekuatan kerajaan. Pola tata masyarakat Majapahit dibedakan atas lapisan-lapisan masyarakat (strata) yang perbedaannya lebih bersifat statis. Walaupun di Majapahit terdapat empat kasta seperti di India, yang lebih dikenal dengan catur warna, tetapi hanya bersifat teoritis dalam literatur istana. ${ }^{24}$ Pola ini dibedakan atas empat golongan masyarakat, yaitu brahmana, ksatria, waisya, dan sudra. Namun terdapat pula golongan yang berada di luar lapisan ini, yaitu Candala, Mleccha, dan Tuccha, yang merupakan golongan terbawah dari lapisan masyarakat

tinggal disuatu daerah tertentu (seperti halnya kadang-kdang terjadi pada perbatasan kota). Adrian Sutedi, Iimplikasi Hukum Atas Sumber Pembiayaan Daerah dalam Kerangka Otonomi Daerah, 97.

${ }^{24}$ Sartono, et al., 700 Tahun Majapahit (Surabaya: Tiga Dara Surabaya, 1993), 39.
Majapahit. ${ }^{25}$ Brahmana (kaum pendeta) mempunyai kewajiban menjalankan enam dharma, yaitu mengajar, belajar, melakukan persajian untuk diri sendiri dan orang lain, membagi dan menerima derma (sedekah) untuk mencapai kesempurnaan hidup dan bersatu dengan Brahman (Tuhan). ${ }^{26}$

Mereka juga mempunyai pengaruh di dalam pemerintahan, yang berada pada bidang keagamaan dan dikepalai oleh dua orang pendeta tinggi, yaitu pendeta dari agama Siwa dan agama Buddha, yang disebut sebagai Saiwadharmadhyaksa dan Buddhadarmadyaksa. Saiwadyaksa mengepalai tempat suci (pahyangan) dan tempat pemukiman empu (kalagyan); Buddhadyaksa mengepalai tempat sembahyang (kuti) dan bihara (wihara); manteri berhaji mengepalai para ulama (karesyan) dan para pertapa (tapaswi). Semua rohaniawan menghambakan hidupnya kepada raja yang disebut sebagai wikuhaji. Para rohaniawan biasanya tinggal di sekitar bangunan agama, yaitu mandala, dharma, sima, wihara, dan sebagainya. Mandala adalah nama komunitas agama di desa, yang ditempatkan di daerah yang terpencil di bukit yang berhutan, sedangkan Sima adalah daerah yang menjadi milik kaum agama dari berbagai sekte, tidak langsung di bawah kekuasaan pejabat istana manapun.

Kaum Ksatria merupakan keturunan dari pewaris tahta (raja) kerajaan terdahulu, yang mempunyai tugas memerintah tampuk pemerintahan. Keluarga raja dapat dikatakan merupakan keturunan dari kerajaan Singasari-Majapahit yang dapat dilihat dari silsilah keluarganya dan keluarga-keluarga kerabat raja tersebar ke seluruh pelosok negeri, karena mereka melakukan sistem poligami secara meluas yang disebut sebagai wargahaji atau sakaparek. Para bangsawan yang memerintah suatu kawasan

${ }^{25}$ Slamet Muljana, Tafsir Sejarah Negara Kretagama (Yogyakarta: LkiS, 2006), 237.

${ }^{26}$ Slamet Muljana, Tafsir Sejarah Negara Kretagama, 237. 
permukiman di ruang lingkup kekuasaan kerajaan dapat dikatakan memiliki hubungan dengan keluarga raja terdahulu dan disebut sebagai parawangsya. Semua anggota keluarga raja masing-masing diberi nama atas gelar, umur, dan fungsi mereka di dalam masyarakat. Bila seseorang diangkat menjadi bangsawan, maka nama pengangkatan akan diberikan kepadanya.

Pemberian nama pribadi dan nama gelar terhadap para putri dan putra raja didasarkan atas nama daerah kerajaan yang akan mereka kuasai sebagai wakil raja. Hak istimewa yang diterima oleh para bangsawan kerajaan bersumber pada penghasilan dari propinsi mereka dan terutama pada penghasilan wilayah yang menjadi hak mereka sendiri.

Waisya merupakan masyarakat yang menekuni bidang pertanian dan perdagangan. Mereka bekerja sebagai pedagang, peminjam uang, penggara sawah dan beternak. Kemudian kasta yang paling rendah dalam catur warna adalah kaum sudra yang mempunyai kewajiban untuk mengabdi kepada kasta yang lebih tinggi, terutama pada golongan brahmana. Golongan terbawah yang tidak termasuk dalam catur warna dan sering disebut sebagai pancama (warna kelima) adalah kaum candala, mleccha, dan tuccha. Candala merupakan anak dari perkawinan campuran antara laki-laki (golongan sudra) dengan wanita (dari ketiga golongan lainnya: brahmana, waisya, dan waisya), sehingga sang anak mempunyai status yang lebih rendah dari ayahnya.

Mleccha adalah semua bangsa di luar Arya tanpa memandang bahasa dan warna kulit, yaitu para pedagang-pedagang asing (Cina, India, Champa, Siam) yang tidak menganut agama Hindu. Tuccha ialah golongan yang merugikan masyarakat, salah satu contohnya adalah para penjahat. Ketika mereka diketahui melakukan tatayi, maka raja dapat menjatuhi hukuman mati kepada pelakunya. Perbuatan tatayi adalah membakar rumah orang, meracuni sesama, mananung, mengamuk, merusak dan memfitnah kehormatan perempuan. ${ }^{27}$

Dari aspek kedudukan kaum wanita dalam masyarakat Majapahit, mereka mempunyai status yang lebih rendah dari para lelaki. Hal ini terlihat pada kewajiban mereka untuk melayani dan menyenangkan hati para suami mereka saja. Wanita tidak boleh ikut campur dalam urusan apapun, selain mengurusi dapur rumah tangga mereka. Dalam undang-undang Majapahit pun para wanita yang sudah menikah tidak boleh bercakap-cakap dengan lelaki lain, dan sebaliknya. Hal ini bertujuan untuk menghindari pergaulan bebas antara kaum pria dan wanita.

Struktur pemerintahan Kerajaan Majapahit mencerminkan kekuasaan yang bersifa teritorial dan disentralisasikan dengan birokrasi yang terperinci sehingga basis kekuasaan sebagian besar berada di tangan birokrasi sekuler, politik dan militer. $^{28}$ Struktur tersebut ada karena terpengaruh kepercayaan yang bersifat kosmologi yang telah menjadi dasar kerajaan-kerajaan Hindu Buddha yang ada Asia Tenggara. Di dalam mekanismenya pemerintah menjamin kehidupan ekonomi para birokrat, sehingga dapat mengeksploitasi pertanian rakyat dan perdagangan.

\section{Pemungut Pajak Kerajaan Majapahit untuk Membangun Ekonomi Wilayah Kekuasaan}

Peranan raja adalah sebagai pusat dari alam sejagad dan sebagai wakil dari dewa-dewa. Berdasarkan konsep kosmologi yang dihayati, seluruh kerajaan Majapahit dianggap sebagai perwujudan dari jagad raya, dan raja disamakan dengan dewa tertinggi yang bersemayam di puncak gunung Mahameru, sehingga raja

${ }^{27}$ Sartono Kartidirjo, "Struktur Sosial dari Masyarakat Tradisional dan Kolonial", dalam Lembaran Sejarah No. 4 (Yogyakarta: FIB UGM, 1969), 7.

${ }^{28}$ Sartono Kartidirjo, "Struktur Sosial dari Masyarakat Tradisional dan Kolonial", 9. 
memegang otoritas tertinggi dan menduduki puncak Hierarki Kerajaan. Jabatan raja diperoleh secara turun temurun atau hak waris. Raja didampingi 14 raja bawahan. Di daerah-daerah terdapat raja-raja bawahan Paduka Bhat,t,āra (Bhre), merupakan keluarga dekat raja yang diberi hak istimewa dalam menjalankan tugas dan tanggung jawab daerah. Yuwarāja (Kumārāja Jasa Putra Parigata) Sebelum menjadi Raja, Putera Mahkota menjadi Raja yang menguasai daerah yang berada di bawah kekuasaan Majapahit. Dewan Pertimbangan Kerajaan (Pahöm Narendra) berada di bawah raja berfungsi mendampingi raja dan dalam mengeluarkan kebijaksanaan raja memiliki otoritas tertinggi, dan perintahnya wajib dilakukan pejabat-pejabat yang ada dibawahnya. Kelompok Dewan āra Saptaprabū" yang anggotanya,t,Pertimbangan Kerajaan bernama "Bhat terdiri dari sanak saudara raja.

Dewan Menteri (Rakyan Mantri Pakira-kiran) Dewan Menteri merupakan Badan Pelaksana Pemerintahan yang terdiri dari lima pejabat, yaitu Rakyan Mapatih atau Patih Hamangkubhumi (Apatih ring Tiktawilwadhika, Rakyan Tumenggung, Rakyan Demung, Rakyan Kanuruhan. Kelima pejabat (para tanda rakyan) tersebut pada zaman Majapahit disebut Sang Panca ring Wilwatikta atau disebut juga Mantri Amancanagara. Rakyan Mapatih adalah pejabat terpenting dalam Dewan Menteri dan biasa disebut Perdana Menteri atau Menteri Utama (Matri Mukya), ia bertugas memimpin Badan Pelaksana Pemerintahan dan mengkoordinasi para menteri. Di daerah-daerah juga terdapat Dewan Menteri yang yang dipimpin Sang Apatih atau Rakyan Apatih, dan itulah yang membedakan antara pemerintahan pusat dan pemerintahan daerah.

Perundang-Undangan Kitab undangundang Majapahit ditemukan di Bali, yaitu Undang Undang Agama. Dalam bahasa Sanksekerta Agama berarti pengetahuan, adat, ajaran. Naskah perundang-undangan yang ditemukan di Bali dan Lombok ditulis dalam bahasa Jawa Tengahan. Kitab perundang-undangan Agama memuat 275 pasa yang berisi tentang: (1) Ketentuan umum mengenani denda; (2) Uraian tentang kejahatan, terutama pembunuhan (astadusta); (3) Perlakuan tentang/ terhadap hamba (kawula); (4) Pencurian (astacorah); (5)Paksaan (walat/aulah sahasa) (6) Jual beli (adol atuku) (7) Gadai (sanda); (8) Utang piutang (ahutang apihutang); (9) Titipan; (10) Mahar (atukon)(11) Perkawinan (karawangan); (12) Perbuatan mesum (paradara) (13) Warisan (drewe kaliliran); (14) Caci maki (wakparusya); (15) Mengangani (dandanparusya); (16) Kelalaian/kenakalan (kagelehan) (17) Perkelahian (atukaran); (18) Tanah (bhumi); (19) Fitnah (duwilatet)

\section{Jenis-jenis Barang yang dapat Dikenakan Pajak Kerajaan}

Keberadaan kerajaan Majapahit ditopang oleh sektor pertanian dan perdagangan. Dengan demikian berarti kerajaan Majapahit adalah kerajaan agraris dan maritim. Di sektor pertanian padi dan hasil pertanian lainnya merupakan tulang punggung perekonomian kerajaan. Pedagang asing yang datang ke Majapahit berasal dari Campa, Khmer, Tahiland, Burma, Srilangka, dan India. Mereka tinggal di beberapa tempat di Jawa dan beberapa di antara mereka ditari pajak oleh pemerintah kerajaan. Komoditi negara asing yang dibawa ke Majapahit adalah sutera dan keramik China, kain dari India, dan dupa dari Arab.

Barang-barang tersebut ditukar dengan rempah-rempah dan hasil pertanian lainnya. Sekitar tahun 1949 M terdapat dua jalur pelayaran dari dan ke China. yaitu jalur pelayaran barat dan jalur pelayaran timur. Jalur pelayaran yang sering digunakan pedagang jawa adalah jalur pelayaran barat, meliputi Vietnam-Thailand-Malaysia- 
Sumatera-Jawa-Bali-Timor. Barang-barang yang diperdagangkan, ${ }^{29}$ yaitu:

1. Barang kebutuhan hidup sehari-hari, berupa bahan makanan, hasil bumi, binatang (ternak, unggas, dan ikan), dan bahan pakaian.

2. Barang produksi kelompok pengrajin, terdapat kelompok pengrajin (pengusaha) di kerajaan Majapahit yang disebutkan dalam prasasti paramiça, barang yang dibuat antara lain tembaga (dyun), keranjang dari daun kelapa (magawai kisi), payung (magawai payuy wlu), upih (mopih), barang anyam-anyaman (manganamanam), kapur (mayhapu). Terdapat juga pengrajin lak/perekat, tali, warna merah, arang, jerat burung dan alat penangkap burung.

3. Barang komoditi internasional, komoditi yang diperdagangkan adalah merica, garam, rempah-rempah, mutiara, kulit penyu, gula tebu, pisang, kayu cendana, emas, perak, kelapa, kapuk, tekstil katun, sutera, belerang dan budak belian.

Mata uang yang digunakan pada zaman Majapahit awal adalah mata uang kepeng dari China. Untuk mendapatkannya Majapahit mengimport mata uang dari China, uang tersebut berasal dari dinasti T'ang (618-907), Song (960-1279), Ming (1368-1644) dan Qing (1644-1911). Hal ini terjadi karena China banyak mengomport merica dari Majapahit, sehingga banyak mata uang kepeng yang mengalir ke Majapahit. ${ }^{30}$ Pusat perdagangan di kerajaan Majapahit adalah pasar yang biasa disebut pkan atau pkěn. Selain perdagangan salah satu sumber kerajaan adalah pajak. Berdasarkan sumber-sumber yang tertulis,

${ }^{29}$ Grace Wong, An Account of the Maritime Trade Routes, between Southeast Asia and China Studies on Ceramic (Jakarta: Puslit Arkenas, 1984), 25.

${ }^{30}$ Amelia, Mata Uang Logam China dari Situs Trowulan (Jakarta: Fakultas Sastra Universitas Indonesia, 1986), 92-95. ditemukan lima pokok bahasan yang berhubungan dengan perpajakan, yaitu pajak dan pembatasan usaha, objek pajak dan kriteria pemungutannya, mekanisme pemungutan pajak, alokasi hasil pemungutan pajak dan kasus-kasus yang berhubungan dengan pemungutan pajak. Pihak kerajaan mengadakan pembatasan usaha terhadap segala jenis benda yang bebas dari pemungutan pajak kerajaan agar hak pembebasan pemungutan pajak kerajaan tidak menjadi tanpa batas. Pajak terdiri dari pajak tanah, pajak usaha, pajak profesi, pajak orang asing, pajak ekspoloitasi Sumber Daya Alam. Pemungutan pajak dilakukan oleh petugas pemungut pajak. Ekonomi Majapahit sebagaimana ekonomi kebanyakan kerajaan di Jawa bertumpu pada kegiatan pertanian, ini terlihat dari pusat kerajaan Majapahit yang juga terletak di pedalaman. Namun jika dilihat lebih jauh Majapahit ekonomi Majapahit juga ditopang oleh perdagangan. Kombinasi kedua unsur ekonomi ini memberi kekuatan bagi Majapahit, yang juga menjadi sifat Jawa sebelumnya yaitu kekuatan demografis.

Pertanian di Jawa sangat menjadikan masyarakat Jawa terikat pada institusi desa yang terikat dalam jaringan yang disebut wanua. Institusi inilah yang kemudian menggerakkan jalannya perdagangan dengan pihak luar. Dalam hal ini perdagangan lebih didominasi oleh perdagangan hasil pertanian pokok. Jaringan pasar lokal antar wanua ini sering disebut sebagai pkên. ${ }^{31}$ Pertanian Jawa sejak sebelum Majapahit sangat kuat. Ini terlihat dari dibuatnya Borobudur beberapa abad sebelumnya yang mengindikasikan pertanian Jawa dapat mencukupi pekerjaan missal tersebut. Selain itu pada masa Majapahit di Jawa juga terdapat beberapa candi yang dibangun.

Kekuatan demografi ini juga mendukung kebijakan ekspansi yang dilakukan oleh Majapahit. Kekuatan

${ }^{31}$ Sartono Kartidirjo, "Struktur Sosial dari Masyarakat Tradisional dan Kolonial", 7. 
demogrsfi ini terlihat sangat besar jika kita membandingkan Jawa pada masa Majapahit dengan luar Jawa. Semananjung Malaya pada abad 14 memiliki penduduk sebanyak 200 ribu saja, seukuran kota kecil masa kini, sedangkan Jawa pada saat yang sama memiliki penduduk sebanyak 3 juta orang. ${ }^{32}$ Majapahit juga melakukan perdagangan dengan bangsa luar. Ini terlihat kebijakan penguasaan langsung pelabuhan di hilir sungai Brantas. Meski ibukota Majapahit terletak jauh di pedalaman, ibu kota terhubung langsung dengan pelabuhan tersebut melalui sungai tersebut. Produkproduk utama Jawa adalah bahan pangan (beras), tekstil kasar (atau kapas) dan tenaga kerja (budak). ${ }^{33}$

\section{Pajak bagi Pembangunan \\ Kemasyalahatan Ekonomi Daerah}

dan

Selain itu motif ekonomi juga terlihat dalam politik ekspansi yang dilakukannnya. Ekspansi-ekspansi yang dilakukannya dilakukan dalam rangka membentuk jaringan kerajaan vassal untuk memperoleh upeti yang akan menjadi produk perdagangan. Selain itu tujuan lain yang lebih utama dalam ekspansi Majapahit adalah untuk memperoleh kontrol atas pelabuhan-pelabuhan dagang utama di Asia Tenggara (dengan kata lain monopoli). Tindak politis yang dilakukan bisa berupa penghancuran pelabuhan atau penaklukan. Sebagai pejabat kerajaan, pemungut pajak ditata dengan rapi dari tingkat desa sampai tingkat pusat. Ditingkat pusat, terdapat tiga kelompok pejabat yang hampir bersamasama, sang mana katrini, yang terdiri dari pengangkur, tawan dan tirip. Ketiga pejabat ini bertanggungjawab atau melakukannya atas rakai. Di bawah pejabat ini terdapat wadwa, parujar, pangurang, pihujang dan kalang. Dilihat salam susunan hirarki jabatan, tiga serangkai pangkur-tawan-tirip

\footnotetext{
${ }^{32}$ MC. Ricklefs, Sejarah Indonesia Modern (Jakarta: Gramedia Pustaka Utama, 1982), 23.

${ }^{33} \mathrm{MC}$. Ricklefs, Sejarah Indonesia Modern, 39.
}

sepertinya termasuk kedalam pejabat pusat sebagaimana tercermin dalam namanamanya menunjukan nama watek, bukan nama desa.

Kitab Nawanatya ${ }^{34}$ yang menyebutkan susunan pemerintahan penting seperti rakai kanuruhan, fungsi utamanya adalah sebagai kepala protocol kerajaan dalam tatacara upacara kerajaan. Selain itu ia juga harus mengurus pedagang-pedagang asing, menyembut dan memenuhi segala kebutuhan tamu-tamu raja. Maka untuk itu rakai kanuruhan harus mengetahui 'semua bahasa' dikatakan juga ia bisa memungut uang dari pedagang asing itu, oleh karena itu pejabat ini memiliki kewenangan untuk memungut pajak dari para pedagang asing. Pejabat lain yang masih samar kedudukannya adalah Mangilala Drwya haji arti harfiyahnya adalah 'mengambil milik raja" orang yang masuk kedalam pejabat ini ditugaskan untuk memungut pajak atas perintah raja.

Pengetahuan dan penamaan sepesifikasi dari pekerja seni banyak diketahui dari pengaturan pajak yang dibebankan kepada mereka atau dari barangbarang yang mereka hasilkan. Mereka yang termasuk golongan ini dalam prasastiprasasti dikenal dengan berbagai istilah diantranya adalah mereka yang diduga sebagai kelompok pengajin adalah angukir (pengukir/pemahat), andyun (pembuat tempayan), angendi (pembuat kendi), apande salwir ning apande (segala macam penempa logam), undhagi (tukang kayu), angapus (pembuat benang atau tali), amaranggi (pembuat hiasan pada bendabenda terbuat dari kayu), anghapu (pembuat kapur), anghanam-anam/agawi kisi, agawi runggi (pembuat keranjang), anghareng (pembuat arang). Sedangkan mereka yang termasuk kategori pekerja seni adalah anglukis (pelukis), awayang (pemain wayang), men-men (pemain pertunjukan

\footnotetext{
${ }^{34}$ Slamet Muljana, Pemugaran Persada Sejarah Leluhur Majapahit (Jakarta: Inti Idayu Press, 1983), 57.
} 
kelling), ijo-ijo (pemain lawak), amidu (penyanyi), amancagah (pembawa berita), anggoda (penggoda, penari ronggeng) dan arketan (pemain topeng). $\mathrm{Di}$ samping mereka terdapat jenis-jenis profesi lain seperti amahang/manwring/ manambu/mangubar, mangala (tukang celup, kadang-kadang dengan warna-warna tertentu); angula (pembuat gula); dan jalagraha (pengangkut air). ${ }^{35}$

Data mengenai para pedagang dalam prasasti $^{36}$ biasanya dikatakan dengan pengaturan mengenai batas-batas barang yang tidak dikenai pajak dan yang kena pajak. ${ }^{37}$ Petunjuk mengenai kemungkinan adanya kelompok-kelompok pedagang dapat diketahui dari jenis-jenis barang yang mereka perdagangkan atau cara-caranya barang-barang dagangan tersebut diangkut. Mengenai jenis barang-barang dagangan ini terdapat tidak kurang dari 31 macam. Meskipun demikian tidak berarti setiap pedagang mempunyai spesialisasi untuk jenis barang dagangan tertentu.

Daftar jenis barang tersebut dapat dikelompokan menjadi empat macam, yakni jenis makanan dan bumbu-bumbuan, jenis sandang, perlengkapan umum dan hewan. Termasuk dalam kelompok makanan dan bumbu-bumbuan terdiri dari bawang (bawang), bras (beras), garam/wuyah (garam), gula, inga (minyak), pipakan/kapulaga (jahe, tanaman jahe);

\footnotetext{
${ }^{35}$ Marwati Djoened Poesponegoro dan Nugroho Notosusanto, Sejarah Nasional Indonesia II (Jakarta: Balai Pustaka, 2008), 292.

${ }^{36}$ Prasasti adalah bukti sumber tertulis yang sangat penting dari masa lalu yang isinya antara lain mengenai kehidupan masyarakat misalnya tentang administrasi dan birokrasi pemerintahan, kehidupan ekonomi, pelaksanaan hukum dan keadilan, sistem pembagian bekerja, perdagangan, agama, kesenian, maupun adat istiadat. Lihat Slamet Muljana, Pemugaran Persada Sejarah Leluhur Majapahit, 48.

${ }^{37}$ Prasasti Biluluk (1366 M0, Biluluk II (1393 M), Biluluk III (1395 M). Menyebutkan tentang pengaturan sumber air asin untuk keperluan pembuatan garam dan ketentuan pajaknya.
}

wahan/pucang sireh (buah-buahan terutama pinang), pja (ikan laut/asin). ${ }^{38}$

Termasuk golongan sandang adalah wasana (pakaian), amahang/kasumbha/pamaja (bahan pewarna), kapas, lawe (benang). Kategori perlengkapan umum adalah galuhan (batu permata), gangsa (perunggu), anganam (keranjang); labeh (kulit penyu), makacapuri (kotak sirih); mangawari (permata), masayang/tamwaga (peralatan tembaga), tambra (lempeng tembaga), timah, wsi (besi). Termasuk dalam kategori hewan adalah hewan besar yang terdiri dari kbo (kerbau), sapi, wdus (kambing), celeng (babi), dan unggas terutama andah (itik). Sebagaian barang-barang di atas dapat diangkut dengan berbagai cara, yakni dipikul, dinaikan di atas punggung kuda, diangkut dengan gerobak, atau dinaikan diatas perahu. Diluar itu terdapat sekelompok orang yang melakukan usaha dalam bentuk jasa pelayanan khususnya pelayanan angkutan, baik menggunakan tenaga hewan, misalnya kuda (atitih) maupun alat angkut lain seperti gerobak (galungan) atau pedati (mapadati) dan perahu (parahu). ${ }^{39}$ Dalam sumber-sumber prasasti sebutan bagi petani selalu dikaitkan dengan wilayah tempatnya hidup.

Istilah wanua atau thani mengacu kepada suatu wilayah dimana para petani atau penduduk desa tinggal. Sebutan untuk penduduknya adalah anak wanua atau anak thani. Dalam prasasti-prasasti banyak yang menyinggung permasalaha pertanian diantaranya adalah adanya yang menyebutkan macam-macam jenis tanah yang dapat didayagunakan oleh para petani, diantaranay yang paling sering disebutkan adalah sawah (sawah), gaga (ladang), kebuan (kebun), renek (rawa). Dari pengelompokan tersebut kitanya terdapat

${ }^{38}$ Rahardjo Supratikno, Peradaban Jawa, 25. Lihat juga Thomas Stamford Raffles, The History of Java (Yogyakarta: Narasi, 2008), 197.

${ }^{39}$ Karsono Saputra, et al., Indonesian Heritage: Sejarah Awal (Jakarta: Buku Antar Bangsa 2002), 21. 
sedikit petunjuk bahwa di antara para petani tersebut dapat dikelompokan berdasarkan kepemilikan tanah dan lahan garapannya. Pada masa Majapahit muncul istilah baruyang berkaitan dengan urusan pertanian, misalnya ambekel tuwuh (pengurus hasil bumi), asedahan thani (petugas yang berhubungan dengan masalah tanah dan pajak), angucap gawe thani (kepala kegiatan wilayah). ${ }^{40}$ Sebagai bagian dari tatanan masyarakat kerajaan, anak wanua/thani menjalankan fungsi utama sebagai pemasok utama dari perekonomian kerajaan. Dari segi kependudukan, kita tidak memiliki cukup data untuk menjelaskan jumlah dan tingkat kepadatannya. Namun, dapat diyakini bahwa sebagai keseluruhan petani merupakan perbesar dari seluruh warga kerajaan. Wilayah inti petani di Jawa Timur berada disekitar lembah sungai Solo dan Brantas. ${ }^{41}$

Tentang retribusi di jaman kerajaan Nusantara tidak disebutkan dengan jelas, namun demikian pada dasarnya dapat diketahui dari isi Prasasti Canggu (Trowulan I) yang berisi tentang aturan dan ketentuan kedudukan hukum desa-desa di tepi sungai Brantas dan Solo yang menjadi tempat penyebrangan. Desa-desa itu diberi kedudukan perdikan $^{42}$ dan bebas dari kewajiban membayar pajak, tetapi diwajibkan memberi semacam sumbangan untuk kepentingan upacara keagamaan dan diatur oleh Panji Margabhaya Ki Ajaran Rata, penguasa tempat penyeberangan di Canggu, dan Panji Angrak saji Ki Ajaran Ragi, penguasa tempat penyebrangan di Terung.

\footnotetext{
${ }^{40}$ Slamet Muljana, Nagara Kretagama dan Tafsir Sejarahnya (Jakarta: Bhatara Karya Aksara, 1979), 26.

${ }^{41}$ Slamet Muljana, Menuju Puncak Kemegahan: Sejarah Kerajaan Majapahit (Yogyakarta: Pelangi Aksara, 2005), 11.

${ }^{42}$ Prasasti Kamban (941 M) Meyebutkan bahwa apada tanggal 19 Maret 941 M, Sri Maharaja Rake Hino Sri Isanawikrama Dyah Matanggadewa meresmikan desa Kamban menjadi daerah perdikan (jalur lalulintas).
}

\section{KESIMPULAN}

Esensi dari kebijakan otonomi pajak jaman kerajaan Majapahit terletak pada kemandirian daerah untuk membuat regulasi dan perencanaan berkaitan dengan pajak yang telah diotonomkan. Pusat tidak hanya memberikan kewenangan kepada daerah pada aspek pajak yang tidak "potensial" meningkatkan Ekonomi daerah, tetapi juga dapat dibagi beberapa jenis pajak lainnya. Pemberian kewenangan kepada daerah pada objek pajak yang lebih luas sebagai respons terhadap tuntutan demokratisasi dalam bingkai desentralisasi, dengan cara memberikan kewenangan kepada daerah akan meningkatkan partisipasi rakyat.

\section{DAFTAR PUSTAKA}

Adji, Krisna Bayu dan Sri Wintala Achmad. Sejarah Perang-perang di Bumi Jawa dari Mataram Kuno hingga Pasca Kemerdekaan Republik Indonesia. Yogyakarta: Araska, 2014.

Amelia. Mata Uang Logam China dari Situs Trowulan. Jakarta: Fakultas Sastra Universitas Indonesia, 1986.

Azhary. Negara Hukum Indonesia, Analisis Yuridis Normatif tentang Unsurunsurnya. Jakarta: Universitas Indonesia, 1995.

Basah, Sjachran. Rangkuman Sari Perkuliahan Ilmu Negara I. Bandung: Grafika Unit II, 1967.

Busroh, Abu Daud dan Abubakar Busro, Asas-asas Hukum Tata Negara. Jakarta: Ghalia Indonesia, 1983.

Busroh, Abu Daud. Ilmu Negara. Jakarta: Bumi Aksara, 1990.

Davey, Kenneth J. Pembiayaan Pemerintah Daerah Praktik Internasional dan Relevansinya bagi Dunia Ketiga, terj. Amanullah, et.al. Jakarta: Universitas Indonesia, 1988.

Departemen Pendidikan Nasional, Kamus Besar Bahasa Indonesia Edisi III. Jakarta: Balai Pustaka, 2005. 
Ismail, Tjip (eds.). Pengaturan Pajak Daerah Indonesia. Jakarta: Yellow Printing, 2007.

Kartidirjo, Sartono. "Struktur Sosial dari Masyarakat Tradisional dan Kolonial", Lembaran Sejarah No. 4. Yogyakarta: FIB UGM, 1969.

Mardiasmo. Otonomi dan Managemen Keuangan Daerah. Yogyakarta: Penerbitan Andi, 2002.

Muljana, Slamet. Menuju Puncak Kemegahan: Sejarah Kerajaan Majapahit. Yogyakarta: Pelangi Aksara, 2005.

Muljana, Slamet. Nagara Kretagama dan Tafsir Sejarahnya. Jakarta: Bhatara Karya Aksara, 1979.

Muljana, Slamet. Pemugaran Persada Sejarah Leluhur Majapahit. Jakarta: Inti Idayu Press, 1983.

Muljana, Slamet. Tafsir Sejarah Negara Kretagama. Yogyakarta: LkiS, 2006.

Poesponegoro, Marwati Djoened dan Nugroho Notosusanto, Sejarah Nasional Indonesia II. Jakarta: Balai Pustaka, 2008.

Raffles, Thomas Stamford. The History of Java. Yogyakarta: Narasi, 2008.

Raharjo, Satjipto. Penegakan Hukum Suatu Tinjauan Sosiologis. Yogyakarta: Genta Publishing, 2009.

Rahayu, Siti Kurnia. Perpajakan (Konsep, Teori, dan Isu). Jakarta: Kencana, 2006.

Ricklefs, MC. Sejarah Indonesia Modern. Jakarta: Gramedia Pustaka Utama, 1982.

Rumokoy, Donald A. Dimensi-dimensi Pemikiran Hukum Administrasi Negara, Cet-2. Yogyakarta: UII Press, 2002.

Saputra, Karsono, et al. Indonesian Heritage: Sejarah Awal. Jakarta: Buku Antar Bangsa 2002.

Sartono, et al., 700 Tahun Majapahit. Surabaya: Tiga Dara Surabaya, 1993.

Supratikno, Rahardjo. Peradaban Jawa. Jakarta: Komunitas Bambu, 2002.
Supratikno, Rahardjo. Peradaban Jawa. Jakarta: Komunitas Bambu, 2002.

Sutedi, Adrian. Iimplikasi Hukum Atas Sumber Pembiayaan Daerah dalam Kerangka Otonomi Daerah. Jakarta: Sinar Grafika, 2009.

Undang-Undang Nomor 32 Tahun 2004 tentang Pemerintahan Daerah.

UUD 1945 hasil amandemen ketiga.

Wong, Grace. An Account of the Maritime Trade Routes, between Southeast Asia and China Studies on Ceramic. Jakarta: Puslit Arkenas, 1984. 